\title{
EU Food Safety Standards, Pesticide Use and Farm-level Productivity: The Case of High-value Crops in Kenya
}

\author{
Solomon Asfaw, Dagmar Mithöfer and Hermann Waibel ${ }^{1}$
}

(Original submitted July 2008, revision received January 2009, accepted February 2009.)

\begin{abstract}
This article provides an empirical analysis of the impact of European Union (EU) private food safety standards on pesticide use and farm-level productivity among small-scale vegetable producers in Kenya. We apply an extended threestage damage control production framework, accounting for multiple endogeneity problems, to farm-level data collected from a random cross-sectional sample of 539 small-scale producers. Estimation results show that farmers producing vegetables for the domestic market use significantly lower quantities of pesticides than do export farmers. However, contrary to findings elsewhere, the econometric evidence here shows that both domestic and export-oriented vegetable farmers in Kenya use pesticides at levels below the economic optimum. The results also show that the adoption of standards by export farmers does not have any significant impact on total pesticide use. However, adopter categories are distinguishable in terms of types of pesticide used, i.e. adopters use safer pesticides based on World Health Organization (WHO) classification. The third-stage structural revenue model results demonstrate that adoption of standards has a positive and significant impact on revenue raised in vegetable production. Nevertheless, farmers producing for the export market are indistinguishable from those producing for the domestic farmers in terms of the total
\end{abstract}

\footnotetext{
${ }^{1}$ Solomon Asfaw is Regional Scientist (Economist), International Crops Research Institute for the Semi-Arid Tropics (ICRISAT), PO Box 39063-00623, Nairobi, Kenya. Tel: +254207224551; Fax: +254207224001; E-mail: s.t.asfaw@cgiar.org for correspondence. Dagmar Mithöfer is Scientist (Economist), International Centre of Insect Physiology and Ecology (ICIPE), Box 30772-00100, Nairobi, Kenya. Hermann Waibel is Professor, Institute of Development and Agricultural Economics, Leibniz University of Hannover, Königsworther Platz 1, 30167 Hannover, Germany. The authors gratefully acknowledge financial support from the German Development Cooperation (BMZ/GTZ) and the technical support by the Kenyan Ministry of Agriculture and export companies. We thank the farmers involved in the survey and the enumerators who collected the data. We would further like to sincerely thank the Editor and the anonymous referees for their helpful comments on earlier versions of this paper. Any remaining shortcomings are our own.
} 
revenue earned from producing vegetables during the rainy season, on a 'per acre' basis. Although standards can potentially prevent resource-poor smallholders from maintaining their position in the lucrative export markets, they can also result in positive changes in the production systems of those small-scale farmers who adopt it, as shown by these results.

Keywords: Damage control; food safety standards; high-value crops; Kenya; productivity.

JEL classifications: $Q 13, Q 17$.

\section{Introduction}

Horticultural exports have grown dramatically in many sub-Saharan African countries while many other agricultural export commodities have faced stagnation and, until very recently, declining world market prices. The Kenyan horticultural export industry has been the most successful and is now by far the largest exporter of vegetables to the European Union (Government of Kenya, 2006). Vegetable exports have increased rapidly over the last decade, surpassing coffee - historically, Kenya's most foreign exchange-earning export crop - as the nation's second major source of foreign exchange in the agricultural sector after tea. The promotion of non-traditional export crops like horticultural commodities has often been proposed as a pro-poor development strategy to reduce poverty in many sub-Saharan countries, including Kenya (Dolan, 2001). In many European countries, what was once a small-scale trade in Asian vegetables, such as chillies or okra sold to wholesale markets, is now high volume and dominated by the biggest supermarkets (Dolan, 2001). The increase in demand for high-value horticultural produce by consumers in developed countries has encouraged farmers in developing countries to intensify production through the increased use of purchased inputs. In horticultural crops, agrochemical inputs such as pesticides play an important role in meeting the quality requirements of wholesale and retail agents, i.e. the delivery of produce with specific physical attributes, such as colour, shape, size and spotlessness (Thrupp et al., 1995).

While agrochemical inputs contribute to increased production and improved quality, high levels of pesticide use have been associated with negative externalities such as short- and long-term human health effects (Antle and Capalbo, 1994; Antle and Pingali, 1994; Pingali et al., 1994; Ajayi, 2000; Wilson and Tisdell, 2001); ecological effects on non-target plants and animals (Thrupp et al., 1995; Pimentel and Greiner, 1997); and damage to soil and water quality of the agro-ecosystem (Pimentel and Greiner, 1997). Increasingly, the prevailing production methods, as well as maximum pesticide residue limit (MRL) have resulted in food safety and sustainability concerns for both domestic and foreign consumers. Retailers and consumers in the importing European countries have become increasingly concerned about the prevailing production methods in the exporting countries. Various rules and regulations have been put in place to protect consumers and farm workers from pesticide intoxication and restore consumer confidence. The European Union (EU), Kenya's major export market, has enacted legislation on traceability, maximum pesticide 
residue limits, and sanitary and phytosanitary requirements. Supermarket chains in Europe have also developed prescriptive, production-oriented standards, e.g. the EU Retailers Produce Working Group for Good Agricultural Practices (GlobalGAP), ${ }^{2}$ which is relevant to growers of fresh fruit and vegetables and requires mandatory certification by an independent and internationally accredited certification body.

The GlobalGAP schemes are based on compliance with four main criteria: food safety, environmental protection, occupational health and safety, and animal welfare. The food safety criteria are based on the application of Hazard Analysis Critical Control Point (HACCP) principles, while criteria for the environment are designed to minimise the negative effects of agricultural production. While a minimal level of occupational health and safety is part of GlobalGAP, this is not regulated through in-depth audits of social conditions. Compliance with GlobalGAP is assessed by use of control points, which are classified into three levels of importance: 'major musts', 'minor musts' and 'recommendations'. Major musts are standards that have to be met with $100 \%$ compliance (GlobalGAP, 2004). All control points that relate to food safety, and some points associated with occupational safety, belong to this category. At present, over 250 control points have been identified in GlobalGAP for fresh fruit and vegetables, of which over 50\% define criteria for the correct use of chemicals for pre- and postharvest treatment (GlobalGAP, 2004). To comply with these standards, producers generally have to change their production technology, e.g. switch to less harmful pesticides and invest in structures such as grading sheds, charcoal coolers, disposal pits, toilet and washing facilities, and pesticide stores.

Some argue that such stringent food safety standards pose major challenges to continued small-scale producers' success in international markets for high-value food products, such as fruit and vegetables (Augier et al., 2004). Yet others argue that such standards can play a positive role, at least in some cases, providing the catalyst and incentives for the modernisation of export supply and regulatory systems, for example through the adoption of safer and more sustainable production and processing practices (Jaffee and Henson, 2004; Maertens and Swinnen, 2006). Such standards also play a positive role in encouraging investment in new technologies. Although compliance with standards is associated with substantial costs, those such as GlobalGAP also provide potential direct and indirect benefits to the farmers. Previous research has shown that adoption of standards can have a positive effect on income (Asfaw et al., in press) although for smallholders it takes longer to recover their investments (Mausch et al., 2008). In addition to the direct financial impact, one might consider the positive health and environmental impacts stemming from changes in pesticide use and hygiene practices associated with adoption as major non-financial benefits. This paper extends the existing analysis to capture pest

\footnotetext{
${ }^{2}$ This study was conducted when EurepGAP, Version 2.1 (October 2004) was relevant. Since then, EurepGAP has changed its name and logo to 'GlobalGAP', arguing that its proclaimed role in promoting the harmonisation of good agricultural practices schemes had moved beyond Europe. The name change was announced at the 8th EurepGAP Conference, the EurepGAP Asia Conference, held in Bangkok on 6 and 7 September 2007. Therefore, throughout this paper the term 'GlobalGAP' is used, and can be considered as synonymous to 'EurepGAP'.
} 
management and examines the impact of GlobalGAP ${ }^{3}$ standards on productivity and changes in pesticide use.

Using farm-level data collected from a random cross-sectional sample of 539 Kenyan small-scale vegetable producers, this paper deals with the following questions: (i) How do smallholder export vegetable producers differ from domestic vegetable producers in terms of pesticide use and total revenue? (ii) Does the adoption of production standards affect the use of pesticides among export producers? and (iii) Does the adoption of production standards affect the revenue of export producers? To answer these questions, an econometric model is applied, taking into account potential problems of endogeneity and/or selectivity with respect to pesticide use, the choice of whether to produce for export and the adoption of standards.

In addressing these objectives, the contribution of this paper to the literature is threefold. First, there is limited empirical evidence to test the hypothesis that food safety standards confer a positive external effect on the farmers adopting it. While some prior studies have analysed the income effect of standards, this study investigates the link between adoption of food safety standards, pesticide use and productivity. Second, in much of the previous literature on private standards, self-selectivity (or endogeneity of adoption of standards) is ignored. The decision to participate in the export market and, therefore, adopt the relevant food-safety standards is not a random event and depends on a number of observable and unobservable factors. This paper addresses the issue using an extended three-stage damage control production function framework. Third, this paper also draws upon a relatively large sample dataset, which was collected via re-call and a season-long monitoring survey.

The remainder of the paper is organised as follows. Section 2 discusses the analytical model and the data. Section 3 presents the empirical results and in section 4 conclusions are drawn and some further implications are noted.

\section{Data and Methods}

\subsection{Survey design and data}

A multi-stage sampling procedure was used to select districts, sub-locations ${ }^{4}$ and small-scale vegetable producers. In the first stage, five districts were selected from the two major vegetable-producing provinces (namely Nyeri, Kirinyaga and Murang'a districts in Central Province, and Meru Central and Makueni districts in Eastern Province) based on the intensity of export vegetable production, agro-ecology, types of crop produced and accessibility. Meru district is located at a higher altitude (above 2,300 m) primarily producing French beans, while Nyeri, Kirinyaga and Murang'a districts are situated at a middle altitude (1,850-2,100 m), producing

\footnotetext{
${ }^{3}$ Besides GlobalGAP there are other standards such as British Retail Consortium (BRC), Hazard Analysis Critical Control Point (HACCP), Tesco's Nature Choice (TNC) and ISO 9001:2000 that are relevant for the sector in Kenya. Nevertheless, these standards are more stringent than GlobalGAP and are primarily adopted by large-scale producers. There was no smallholder group certified under these other standards during our survey period and hence our study mainly focuses on smallholders producing under GlobalGAP.

4 'Sub-location' is the lowest administrative unit in Kenya and is composed of small villages.
} 
a range of green beans and peas. Makueni district is located at a lower altitude (600-1,100 m), mainly producing Asian vegetables such as okra, chillies and aubergines. These districts represent the major export vegetable-producing areas, which cover approximately half of all smallholder export vegetable producers in Kenya (Mithöfer et al., 2008). As the number of export vegetable producers among the districts varies, and to ensure that every element in the target population has an equal chance of being included in the sample, we used the probability proportional to size (PPS) sampling technique. Overall, 21 sub-locations were randomly selected from the five districts by PPS sampling procedures and a total of 539 vegetable producer households (both export and domestic market) were selected randomly for the interviews. Of these 149 are GlobalGAP adopter export farmers, 290 are non-adopter export farmers and 100 are domestic vegetable producers. GlobalGAP adopters in this case are defined as small-scale export producers who have either already obtained GlobalGAP certification or are in the process of obtaining the certificate under Option 2. ${ }^{5}$ Non-adopters are export farmers who are not involved in any way in the process of GlobalGAP certification.

Data collection took place during the 2005/2006 cropping season. For each randomly selected farmer, the survey consisted of a single visit (re-call survey) and a season-long monitoring of household production practices. The season-long monitoring data were collected for both dry (November 2005 to February 2006) and rainy seasons (May to August 2006). However, many sampled farmers faced a total crop failure resulting from drought during the dry season. It was very difficult to establish an input-output relationship when the yield harvested was zero for most sampled farmers. Although the dry season information is scanty for econometric modelling, it is sufficient to further discuss results and implications for production cost (pesticide use) and income streams throughout the year.

The data were collected by trained enumerators supervised by the first author, using structured questionnaires. The re-call survey questionnaire covered specific information on the characteristics of household members, household income (both farm and off-farm), household assets such as land and livestock ownership, farm machinery and household equipment, as well as access to different services such as credit, irrigation, formal contracts and group membership. The season-long monitoring survey form was used to record inputs and outputs related to vegetable production. Besides personal interviews, a series of formal and informal farmer group discussions was also conducted to complement the household survey. The data collected via group discussion include qualitative information on the challenges of adopting GlobalGAP, contractual relationships between farmers and exporters, problems associated with export production and marketing, etc. This information is primarily used to explain the findings of the econometric results.

\footnotetext{
${ }^{5}$ GlobalGAP offers four types of certification, although in Kenya at the time of the survey only two of them were applied. Under Option 1 individual farmers apply for certification and under Option 2 a group of farmers applies for a group certificate. Farmers must invest in the infrastructure necessary for GlobalGAP, establish an internal management and control system, perform individual self-inspections and group internal inspections before receiving an external verification by a certification body (GlobalGAP, 2004).
} 


\subsection{Analytical model}

Following the work of Lichtenberg and Zilberman (1986), Ajayi (2000), Huang et al. (2002), Qaim (2003), Qaim and Zilbermann (2003), Pemsl (2006) and Shankar and Thirtle (2005), this study takes the 'damage control' approach to establishing pesticide productivity and computing economic optima for pesticide use. The Cobb Douglas production function with logistic damage control function can be represented as:

$$
\ln (Q)=\ln (a)+\sum_{i=1}^{n} \beta_{i} \ln \left(W_{i}\right)+\gamma G_{i}+\ln \left(1+\exp \left(\lambda-\alpha X_{p}\right)\right)^{-1}+v
$$

where $Q$ denotes total revenue per acre from vegetables, ${ }^{6}$ the vector $W_{i}$ includes labour, fertiliser, seed, number of vegetable crops grown, decision to produce for export, price of vegetable output, type of vegetable produced, access to irrigation, distance to market, quality of soil, age of the household head and $G_{i}$ denotes adoption of the GlobalGAP standard. A series of district dummy variables is also introduced in the model to capture the heterogeneity in location-specific factors. ${ }^{7}$ The $\beta_{i}$ values are the respective coefficients to be estimated, $\lambda$ is constant, $\alpha$ is the parameter to be estimated for pesticide use and $X_{p}$ in the logistic damage function framework.

The effect of GlobalGAP adoption on revenue can be estimated correctly only if the regression model is properly specified. It is obvious that the introduction of a variable representing vegetable type in the model is crucial because price of output, yield and cost of inputs can potentially be confounded with the type of vegetable produced. However, as mentioned earlier, production of export vegetables among smallholders is mostly district-specific, i.e. Meru farmers primarily produce French beans, Makueni farmers produce Asian vegetables and farmers in the remaining districts produce peas and French beans. The inclusion of a vegetable type variable together with the district dummies can potentially create a multicollinearity problem. To check the robustness of the results to different specifications, we performed a sensitivity analysis with and without a variable representing vegetable type.

Another long-standing problem with direct estimation of the production function is that the inputs are treated as exogenous, whereas the farmers decide their levels. Although this problem applies to all inputs, it is especially true of pesticides, as they are often applied in response to pest pressure (Huang et al., 2002). Hence, it is possible that the covariance of $x_{p}$ and the residuals of the revenue function is non-zero, indicating a systematic relationship among pests, pesticide use and vegetable yields; a condition that would bias parameter estimates of the impact of pesticides on output. Equation (1) also does not account for the possible selection bias of production of export vegetables and the adoption of GlobalGAP in the production function equation. The decision (a) to participate in the export market and (b) to adopt standards may be determined by unobservable variables that may also affect productivity. If this is the case, it leads to biased estimates of the impact of the adoption of

\footnotetext{
${ }^{6} \mathrm{We}$ used total revenue instead of total yield to capture the variation in the quality of the produce and at the same time avoid the potential problem of aggregation error.

${ }^{7}$ Average annual precipitation is not included in the model due to lack of data. The district dummies included in the model partially capture the variation in rainfall.
} 
GlobalGAP. Table 1 gives an overview of the model specification for revenue and pesticide use function (without consideration of potential endogeneity problems) and definition of variables included in the model.

A Wu-Hausman specification test (Hausman, 1978) was performed to test the null hypotheses that (a) pesticide use, GlobalGAP adoption and decision to produce for export market are exogenous in the revenue function; and (b) GlobalGAP adoption and decision to produce for export market are exogenous in pesticide use function, before further econometric analysis. The estimated $\mathrm{Wu}-\mathrm{Hausman}$ chi-squared statistics are reported in Table 2.

The $P$-values of the estimated $F$-test statistics show that the exogeneity hypothesis is rejected in the revenue function for GlobalGAP adoption, pesticide use and decision to produce for the export market at the 5\% and $15 \%$ level of significance, respectively. The exogeneity hypothesis for GlobalGAP adoption and decision to produce for the export market in pesticide use function is rejected at the $5 \%$ and $15 \%$ level of significance, respectively. The results of the $\mathrm{Wu}-\mathrm{Hausman}$ specification test suggest that farmers' decisions to produce for the export market, adopt GlobalGAP and pesticide input use are endogenous in the revenue production function model and need to be accounted for to obtain efficient and consistent estimates. It is most likely that the destination markets and compliance with standards affect product prices received as well as input costs incurred. If this is the case, prices are not exogenous of the dependent variable revenues and costs. So it could be the case that because of the specification used, these equations will exhibit RHS endogeneity. Yet endogeneity would remain a problem for the decision sequence in question with a different specification that did not conflate price with the dependent variable, i.e. total yield and pesticide quantity as a dependent variable instead of total revenue and pesticide cost.

To account empirically for this multiple endogeneity and/or selectivity problem in the production function, we use a model that consists of three stages (Rivers and Vuong, 1988; Wooldridge, 2002; Arendt and Holm, 2006) as follows:

Stage 1: Adoption equation

$$
G_{i}^{*}=\beta Z_{i}+u_{i}
$$

Stage 2: Reduced-form regression

$$
\begin{aligned}
& X_{p}^{*}=\alpha V_{i}+\gamma G_{i}+e_{i} \\
& G_{i}= \begin{cases}1 & \text { if } G_{i}^{*}>1 \\
0 & \text { otherwise }\end{cases}
\end{aligned}
$$

Stage 3: Structural equation

$$
\ln (Q)=\beta_{i} \ln \left(W_{i}\right)+\gamma G_{i}+\ln \left(1+\exp \left(\lambda-\alpha X_{p}\right)\right)^{-1}+v_{i}
$$

where $G_{i}^{*}$ is the unobservable or latent variable for GlobalGAP adoption, $Z_{i}$ is a non-stochastic vector of observed farm and non-farm characteristics determining adoption (number of adult females, age of household head, educational attainment, access to facilities, level of agricultural training, total hours spent listening to radio per week, total hours spent watching television per week, use of mobile phone, 
Table 1

Model specification and definition of variables

Model specification without considering potential endogeneity problems

TRVG = f [SEED, FERT, LABO, PRES, CRNU, PEST, CRTY, ADOP, AGEH, PRPR, MARK, FERL, IRRI, vegetable type dummies, district dummies]

PEST $=\mathrm{f}$ [CRTY, ADOP, PEPR, FEPR, PRES, HHSI, CONT, AGEH, DIST, GROU, SYPT, FACI, TRAI, CRED, APPL, FERL, vegetable type dummies, district dummies]

\begin{tabular}{ll} 
Variable & Definition \\
\hline TRVG & Total revenue of vegetables per acre per cropping season (KSh) \\
PEST & Total cost of pesticide use per acre per cropping season (KSh) \\
AGEH & Age of the household head (years) \\
HHSI & Household size (adult equivalent) \\
SEED & Seed cost per acre per cropping season (KSh) \\
FERT & Fertiliser cost per acre per cropping season (KSh) \\
LABO & Labour cost per acre per cropping season (KSh) \\
CRTY & Choice to produce for export $(1$, if export market, 0 if domestic market) \\
CRNU & Number of vegetable crops grown per cropping season \\
PRPR & Average vegetable output price $(\mathrm{KSh} / \mathrm{kg}) \dagger$ \\
PRES & Pressure of pest (scores from 1 to 9$)+$ \\
ADOP & Adoption of GlobalGAP dummy \\
PEPR & Price of pesticide (KSh/g) \\
FEPR & Price of fertiliser (KSh/kg) \\
SYPT & Pesticide poisoning cases one year prior to the survey \\
FACI* & Facility index \\
MOBI & Number of years using mobile phone prior to the survey period \\
TRAI & Number of major agricultural training subjects attended in the past three \\
& years prior to 2005 \\
GROU & Number of years the household head has been a group member \\
CONT & Number of years the household had a formal contract \\
DIST & Distance to extension service (km) \\
CRED & Amount of credit used for the past 3 years prior to 2005 ('000 KSh) \\
OFFF & Previous occupation was in non-agriculture dummy \\
EXPO & Number of years the head has been producing for the export market prior \\
& to survey period \\
APPL & Primary applicator of pesticide $(1$, if household member, 0 if casual labour) \\
MARK & Distance to nearest local market (km) \\
FERL & Proportion of land that is fertile as percentage (\%) \\
IRRI & Access to irrigation dummy \\
\hline &
\end{tabular}

Notes: *Facility index: $D_{h}=\Sigma D_{i h}\left(1-P_{i}\right), P_{i}=n_{i} / n$ where $D_{i h}=1$ if household $h$ has access to facility $i$; the facilities are having cemented floor, number of rooms, access to piped water, and being less than 100 metres from water source; $P_{i}$ is the probability of having facility $i ; n_{i}=$ number of households which have a facility $i$; and $n=$ total number of households (McCulloch and Ota, 2002).

$\dagger$ Average product price is computed as the weighted mean price per kilogram of export vegetables (French beans, peas and Asian vegetables) and domestic vegetables (cabbage, tomatoes and kales) separately for the sample households.

$\$$ Pest pressure is measured on a scale from 1-9 where 1 represents a very low pest pressure and 9 represents the very highest. It is evaluated subjectively by the farmers. 
Table 2

Results of $\mathrm{Wu}-$ Hausman specification tests

\begin{tabular}{|c|c|c|}
\hline Null hypothesis & $\begin{array}{l}\text { Wu-Hausman } \\
F \text {-test statistics }\end{array}$ & $P$-value \\
\hline $\begin{array}{l}\text { Exogeneity of GlobalGAP adoption discrete choice } \\
\text { in revenue function }\end{array}$ & 3.78 & $0.053^{*}$ \\
\hline Exogeneity of pesticide inputs use in revenue function & 1.55 & $0.138 \dagger$ \\
\hline $\begin{array}{l}\text { Exogeneity of choice to produce for export market } \\
\text { in revenue function }\end{array}$ & 1.48 & $0.145 \dagger$ \\
\hline $\begin{array}{l}\text { Exogeneity of GlobalGAP adoption discrete choice } \\
\text { in pesticide use function }\end{array}$ & 4.15 & $0.043 * *$ \\
\hline $\begin{array}{l}\text { Exogeneity of choice to produce for export market } \\
\text { in pesticide use function }\end{array}$ & 1.60 & $0.114 \dagger$ \\
\hline
\end{tabular}

Notes: $\$$ Statistical significance at the $0.01(* * *), 0.05(* *), 0.1(*)$ and $0.15(\dagger)$ level of probability.

contact to extension service, access to formal contract, duration of group membership, years of export production, use of irrigation and participation in off-farm activities), $X_{p}^{*}$ denotes the pesticide use (includes insecticide, herbicide and fungicide), $V_{i}$ is a vector of exogenous variables thought to affect pesticide use (age of household, household size, pest pressure, price of pesticide, price of fertiliser, level of agricultural training, access to extension service, access to credit service), $G_{i}$ is the predicted value of GlobalGAP adoption from stage $1, Q_{i}$ denotes total revenue per acre from export vegetables, $W_{i}$ represents covariates expected to influence the structural revenue equation, $X_{p}$ denotes the predicted value of pesticide use from stage 2 , and $u_{i}, e_{i}$ and $v_{i}$ are random disturbances associated with the adoption of GlobalGAP, pesticide use and the revenue model, respectively.

The purpose of stages 1 and 2 is to eliminate the problem of endogeneity of GlobalGAP adoption and pesticide use in the structural model. To solve this problem, the endogenous variable is first regressed on the instruments and then the estimated value of the endogenous variable is included in the structural equation instead of the endogenous variable itself (Greene, 1997; Wooldridge, 2002). So in stage 1, we estimate the probability of adopting GlobalGAP as a function of a number of variables that explain the adoption decision using probit estimation. From this model, we construct an estimate of predicted value of GlobalGAP adoption, which is then included in stages 2 and 3 of our model. In stage 2 of our model, pesticide use is estimated based on the reduced-form equation, which contains the instruments, the predicted value of GlobalGAP adoption from stage 1, and a number of control variables. In stage 3 the structural equation incorporating the logistic damage control function is then estimated. In this stage, the dependent variable of interest, here the total revenue per acre from vegetable production, is regressed on the estimated values of the endogenous variables from stages 1 and 2 . In doing so, we control for the endogeneity problem of both variables at the same time in our structural model and estimate the impact of GlobalGAP adoption, as well as pesticide use, on revenue.

For the first stage, our identification strategy is based on variations in the stock of social capital enjoyed by different households. Our hypothesis is that the 
probability of a household adopting GlobalGAP is an increasing function of its 'stock of social capital' within the rural community, reflected by three instrumental variables: the number of years a household has been producing for the export market; duration of group membership; the number of years the household has been using a mobile phone. These variables do not have any direct effect on pesticide use and revenue, though they are hypothesised to affect the probability that the household adopts GlobalGAP standards. For the second stage pesticide use function, based on existing literature (Pemsl, 2006), two instruments are chosen: price of pesticide and price of fertiliser. These instruments are highly correlated with pesticide use but do not have any effect on revenue except through the yield effect of pesticide use.

To examine the impact of the participation of smallholders in export vs. domestic market channels on pesticide use and total revenue, we apply the same procedure. At the first stage we estimated the determinants of participation in the export market using the total sample (which includes both domestic and export farmers) to obtain the predicted value of participation. Then we include this variable in the second (pesticide use) function as discussed above. In the third stage the revenue function is estimated by including the predicted value of the decision to produce for the export market, which is obtained from the first stage, and predicted value of pesticide use that is estimated from the second stage pesticide use function. Hence, the pesticide use function and the revenue function are estimated for each stratum, i.e. a total sample that encompasses domestic and export farmers, and a sub-sample that includes only export farmers.

The decision to participate in export is instrumented by a dummy for whether the previous occupation was in non-agriculture. This variable is correlated with participation status but would it be uncorrelated with pesticide use and revenue? If those with more managerial ability choose non-agricultural occupations, then a previous occupation dummy is likely to be correlated with export participation ability. However, such an argument supposes that those with initial careers in non-agriculture had the choice of pursuing a career in export production. This is unlikely to be generally true because family background (especially father's occupation in the Kenyan context) and information (technical and business expertise in export production) are important determinants of the set of initial job alternatives that an individual would consider. Furthermore, there is no compelling reason for management ability to be correlated with the previous occupation dummy. For the second stage, pesticide use is instrumented by price of pesticide and fertiliser. The validity of our results depends to a large extent on the quality of these instruments. We assess the quality of our instrument by using an $F$-test of the joint significance of the excluded instruments. According to Stock and Staiger (1997), the weak instrument hypothesis will be rejected if the $F$-test statistic is greater than 10. Additionally as part of robustness check, we also perform overidentification tests of the model.

\section{Results and Discussion}

\subsection{Descriptive analysis}

The most frequently grown export vegetable is French beans, whereas the most prevalent crops for the domestic market are cabbage, tomatoes and kales. As shown in 
Table 3

Number of growers, farm size, yield and price $(N=539)$

\begin{tabular}{lccccc}
\hline Vegetable types* & Count & Per cent & $\begin{array}{c}\text { Farm size } \\
(\text { acres })\end{array}$ & $\begin{array}{c}\text { Yield } \\
(\mathrm{kg} / \mathrm{acre})\end{array}$ & $\begin{array}{c}\text { Price } \\
(\mathrm{KSh} / \mathrm{kg}) \text { 耳 }\end{array}$ \\
\hline French beans & 298 & 55.3 & 0.35 & 1,732 & 33 \\
Peas & 129 & 23.9 & 0.28 & 2,240 & 42 \\
Asian vegetables $\dagger$ & 40 & 7.4 & 0.38 & 1,416 & 25 \\
Cabbage & 77 & 14.3 & 0.29 & 2,960 & 14 \\
Kale & 47 & 8.7 & 0.22 & 3,968 & 12 \\
Tomatoes & 31 & 5.6 & 0.25 & 2,232 & 18 \\
\hline
\end{tabular}

Notes: *Vegetables produced solely for home consumption are not considered. The list includes only vegetables produced for commercial purposes, either for the domestic or export market.

$\uparrow$ Asian vegetable category includes okra, chillies, karalla and aubergines.

$\$$ The exchange rate at the time of the survey was approximately $72 \mathrm{KSh} / \$ \mathrm{US}$.

Table 3, of the total sample households in the five districts, 55.3\% grow French beans on an average plot size of 0.35 acres per household. Peas and Asian vegetables are grown by $23.9 \%$ and $7.4 \%$ of the sample households, on an average plot size of 0.28 for peas and 0.38 acres for Asian vegetables, respectively. Among vegetables produced for the domestic market, cabbage is produced by about $14.3 \%$ of the sampled households, while kale and tomatoes are produced by $8.7 \%$ and $5.6 \%$ of the sample, respectively. Table 3 gives the number of growers, area allocated to each type of vegetable crop per household, total yield per acre and the average price received per kilogram of output.

Table 4 presents the $t$-test comparison of mean values of selected production variables between export and domestic vegetable producers and GlobalGAP adopter categories. The total yield is significantly higher for domestic vegetable producers. However, total revenue and net revenue ${ }^{8}$ per acre for export vegetable producers are not significantly higher than those of domestic producers in contrast to the findings of McCulloch and Ota (2002). Our results only capture revenue and net revenue in the rainy season, and if year-round production is considered, export farmers are likely to have higher incomes compared with those who produce for the domestic market. With the exception of labour cost and land use, export and domestic vegetable producers are distinguishable by other input costs such as fertiliser, seeds and pesticides. The cost of fertiliser is significantly higher for export vegetable producers, but the cost of seeds is lower compared with their domestic counterparts. It is also clear from the descriptive statistics that domestic vegetable producers use less pesticide and spend less money on them than do export vegetable producers. The results also show that domestic-oriented farmers use less herbicide than exportoriented farmers, but both use similar amounts of insecticide. For example, farmers producing for the domestic market applied $0.87 \mathrm{~kg}$ of pesticides per acre on

\footnotetext{
${ }^{8}$ Net revenue is computed as total revenue from vegetables minus all variable costs, including family labour per cropping season. The value of family labour was approximated by the existing wage rate in the nearest village.
} 


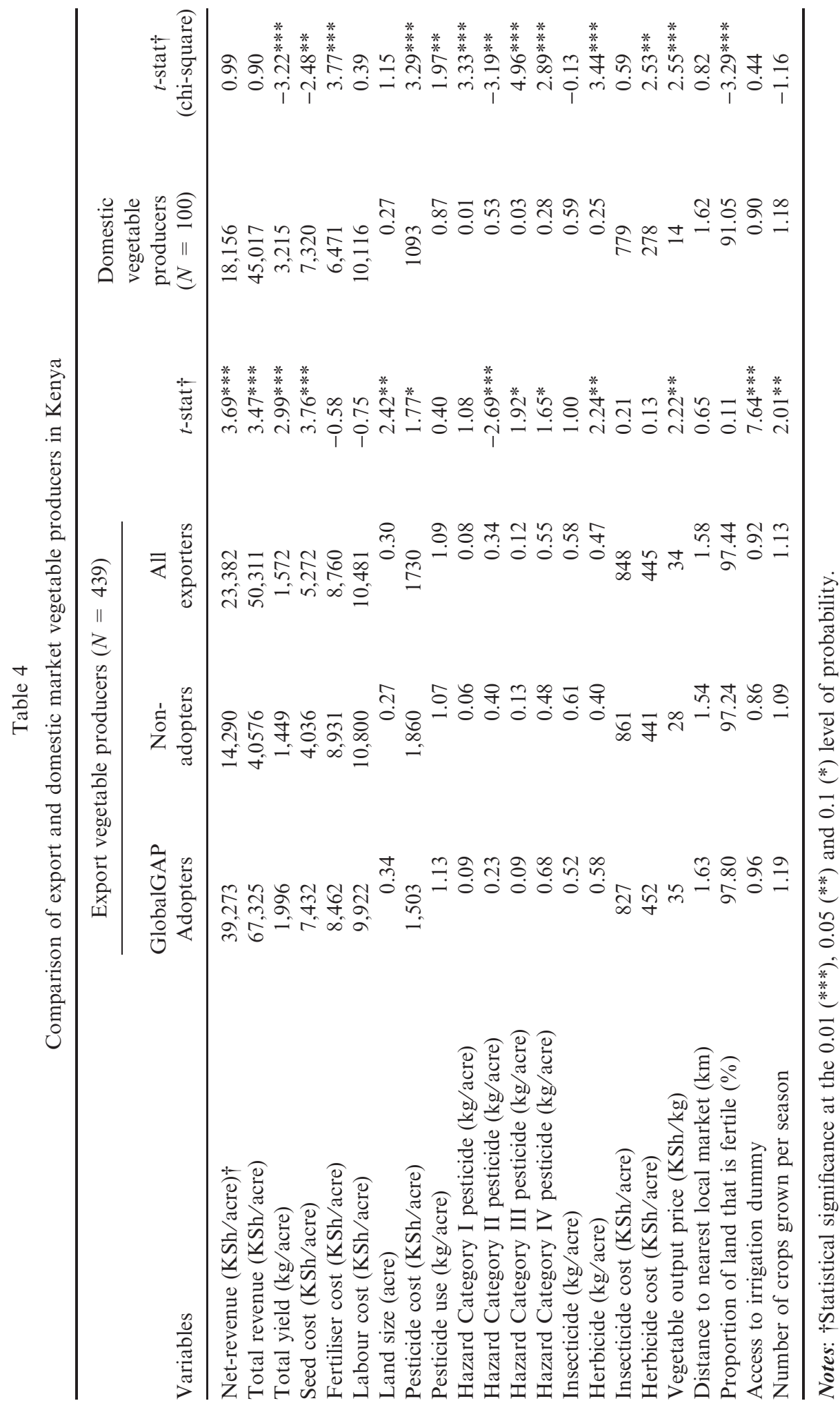


average, whereas export vegetable farmers used $1.10 \mathrm{~kg}$ per acre. The lower pesticide quantities also translate into cost savings for farmers. Domestic vegetable producers spent $1,093 \mathrm{KSh}$ per acre $^{9}$ on pesticides; on average, export farmers spent 1,730 KSh per acre.

GlobalGAP adopters and non-adopters only differ significantly with respect to seed cost and number of crops grown per cropping season. GlobalGAP adopters incur significantly higher seed costs, which might be partially attributed to the high prices for the better quality seed that is demanded by exporters who pursue GlobalGAP standards. We observe that the groups are indistinguishable with respect to total quantity of pesticide used per acre although the associated costs are significantly higher for non-adopters. Besides, if we compare the types of pesticides used among the categories, non-adopters use significantly higher amounts of Hazard Category II and III pesticides, which WHO classifies as highly toxic and toxic, respectively, whereas the adopters use higher amounts of Hazard Category IV, which WHO classifies as moderately toxic. The results also reveal that the adopters use significantly higher amounts of herbicide per acre than the non-adopters even though the extra herbicide quantity does not translate into higher cost. Total yield, total revenue and the net-revenue per acre are all significantly higher for GlobalGAP adopters compared with the non-adopters.

\subsection{Stage 2: pesticide use model results}

As shown in Table 5 the results of both pesticide use functions demonstrate that the model performed well in explaining pesticide use, with reasonable explanatory power for cross-sectional data (adjusted $R$-square values between 0.25 and 0.34 ). Over-identification tests support the choice of the instruments, as do the $F$-test values for the first-stage export crop participation. The $F$-statistic of joint significance of the excluded instruments is greater than 10, thus passing the test for weak instruments. The null hypothesis in the over-identification test is that the instruments are valid. The over-identification tests for the first-stage adoption model however did not support the validity of duration of group membership which was therefore dropped as an instrument. The test does not reject the validity of years of production for export market and use of mobile phones, and hence they were used as instruments.

Most importantly, the regression model results demonstrate the impact of the decision to produce for export market (CRTY) and adoption of GlobalGAP standards (ADOP) on expenditure on pesticides. ${ }^{10}$ The positive and highly significant coefficient on the CRTY variable means that export vegetable producers spend

\footnotetext{
${ }^{9}$ Kenyan Shilling (KSh) is the currency of Kenya. The exchange rate at the time of the survey was approximately $72 \mathrm{KSh} / \$ \mathrm{US} 1$.

${ }^{10}$ The estimation results of a standard ordinary least square (OLS) of pesticide use function are presented in Table 7. The OLS estimates for participation in export market are smaller and insignificant than the instrument variable (IV) estimates in pesticide use function. The OLS estimates underestimate the use of pesticide. The IV and OLS estimates for adoption of GlobalGAP standards also show a difference both in terms of significance and magnitude. The OLS overestimate the reduction in pesticide use. Overall, comparison of the IV with the OLS estimates shows that correction for unobservables is important.
} 
more on pesticides than do domestic vegetable producers. Ceteris paribus, farmers producing export crops spend $28 \%$ more on pesticides than farmers producing domestic crops. ${ }^{11}$ However, with regard to the pesticide use function estimated for export farmers, we observe no significant difference between the adopter categories in terms of cost of pesticide use. This indicates that GlobalGAP adoption does not significantly reduce the pesticide expenditures of smallholder export producers. ${ }^{12}$ Furthermore, there seems, on casual inspection, to be no significant difference in the drivers of pesticide use between the exporters and the total sample, with the possible exception of the MURANGA dummy, though the total sample is dominated by the exporters. This might be attributed to three factors. First, exporters who monitor and enforce compliance with GlobalGAP have higher grading standards and thus place more emphasis on physical appearance of the produce (e.g. spotlessness), which implicitly encourages chemical control of pests and diseases. Second, although GlobalGAP requirements advocate the use of alternative pest control strategies such as integrated pest management (IPM), export farmers rarely resort to this alternative because of the risks associated with the possible outbreak and rapid spread of pests, an outcome that is exacerbated by the tropical climate. Third, export companies that enforce GlobalGAP also indirectly promote the use of chemical control by handing farmers a weekly spray programme and sometimes undertake direct spraying by their technical personnel. These chemicals are often relatively new and selective, and thus expensive and less hazardous, compared with the traditional chemicals available in the market. To examine whether adoption of standards affects the types of pesticide used, we further estimated an alternative function by using the ratio of WHO Hazard Category I and II pesticides to the total pesticides as a dependent variable. The estimation results ${ }^{13}$ demonstrate that the adopter categories are distinguishable in types of pesticide used; i.e. non-adopters use significantly greater amounts of WHO Hazard Category I and II pesticides compared with non-adopters. These findings correspond with the descriptive results presented earlier.

The coefficient of the variable FEPR is negative and statistically significant for both pesticide use functions, whereas the price of pesticide (PEPR) is positively associated. This suggests that the expenditure on pesticide use is inversely related to the price of fertiliser and directly related to pesticide price, which is in line with expectations. Though not necessarily, this might also suggest that demand for pesticides is price inelastic, since otherwise pesticide price increases would result in reduced expenditure. On the other hand, farmers having access to credit services (CRED) spend significantly more on pesticides, suggesting that financial constraints may be one impediment to pesticide use among export farmers. As expected, the

\footnotetext{
${ }^{11}$ When dummy variables are used in a model with a log-transformed dependent variable, the coefficient of the dummy variable multiplied by 100 is not the usual percentage effect of that variable on the dependent variable (Kennedy, 1981). Instead it should be calculated as: $h=100 *\left[\exp \left(\beta_{i}-1 / 2 v\left(\beta_{i}\right)\right)-1\right]$ where $h$ is the percentage change in the level of the dependent variable, $\beta_{i}$ is the estimated coefficient of the dummy variable and $v\left(\beta_{i}\right)$ is the estimated variance of $\beta_{i}$, which is applied in this study.

${ }^{12} \mathrm{We}$ also estimated an alternative function using quantity of pesticide used as a dependent variable and found no significant difference between adopter categories.

${ }^{13}$ The estimation results are available on request from the authors.
} 
Table 5

Results of pesticide use function estimation

\begin{tabular}{|c|c|c|c|c|c|c|}
\hline \multirow[b]{3}{*}{ Variable } & \multicolumn{6}{|c|}{ Amount of pesticide use: ln-total cost (KSh/acre) } \\
\hline & \multicolumn{3}{|c|}{$\begin{array}{c}\text { Domestic and export vegetable } \\
\text { producers }\end{array}$} & \multicolumn{3}{|c|}{$\begin{array}{c}\text { Export vegetable producers } \\
\text { only }\end{array}$} \\
\hline & $\begin{array}{l}\text { Estimated } \dagger \\
\text { coefficient }\end{array}$ & $\begin{array}{l}\text { Standard } \\
\text { error }\end{array}$ & $t$-value & $\begin{array}{l}\text { Estimated } \dagger \\
\text { coefficient }\end{array}$ & $\begin{array}{l}\text { Standard } \\
\text { error }\end{array}$ & $t$-value \\
\hline Constant & $6.83^{* * *}$ & 0.49 & 14.01 & $7.63 * * *$ & 0.53 & 14.52 \\
\hline ADOP estimated & & & & -0.05 & 0.16 & -0.32 \\
\hline CRTY estimated & $0.31 * *$ & 0.14 & 2.27 & & & \\
\hline PEPR & $0.15^{* * *}$ & 0.04 & 3.97 & $0.13 * * *$ & 0.04 & 3.57 \\
\hline FEPR & $-0.03 * * *$ & 0.01 & -3.37 & $-0.03^{* * *}$ & 0.01 & -3.76 \\
\hline AGEH & -0.01 & 0.01 & -1.02 & $-0.01 *$ & 0.01 & -1.74 \\
\hline HHSI & $-0.04 *$ & 0.03 & -1.51 & $-0.04 *$ & 0.03 & -1.61 \\
\hline PRES & $0.06^{*}$ & 0.03 & 1.86 & 0.05 & 0.04 & 1.42 \\
\hline CONT & 0.03 & 0.03 & 0.93 & 0.05 & 0.03 & 1.50 \\
\hline GROU & 0.18 & 0.03 & 0.61 & 0.04 & 0.03 & 1.48 \\
\hline SYPT & 0.60 & 0.04 & 1.56 & 0.05 & 0.04 & 1.17 \\
\hline FACI & -0.12 & 0.10 & -1.23 & $-0.24 * *$ & 0.11 & -2.27 \\
\hline TRAI & $-0.03^{*}$ & 0.02 & -1.71 & -0.03 & 0.02 & -1.32 \\
\hline DIST & $0.09 * * *$ & 0.02 & 3.93 & $0.07 * * *$ & 0.02 & 3.11 \\
\hline CRED & $0.00^{*}$ & 0.00 & 1.81 & $0.00^{*}$ & 0.00 & 1.68 \\
\hline APPL & $0.36^{* *}$ & 0.16 & 2.14 & $0.38 * *$ & 0.18 & 2.12 \\
\hline FERL & -0.01 & 0.02 & 0.67 & 0.03 & 0.02 & 1.11 \\
\hline \multicolumn{7}{|l|}{ DISTRICTS } \\
\hline \multicolumn{7}{|l|}{ MERU (reference) } \\
\hline KIRINYAGA & -0.23 & 0.21 & -1.09 & -0.23 & 0.25 & -0.91 \\
\hline MURANGA & 0.09 & 0.32 & 0.28 & $0.85 * *$ & 0.40 & 2.12 \\
\hline NYERI & -0.01 & 0.20 & -0.08 & 0.16 & 0.23 & 0.68 \\
\hline MAKUENI & $-0.94 * * *$ & 0.31 & -3.07 & $-1.01 * *$ & 0.40 & -2.50 \\
\hline Number of observations & 539 & & & 439 & & \\
\hline$R$-square & 0.28 & & & 0.38 & & \\
\hline Adj. $R$-square & 0.25 & & & 0.34 & & \\
\hline \multicolumn{7}{|l|}{ Test of instruments } \\
\hline$F$-test (first stage) & 11.49 & & & 9.61 & & \\
\hline$P$-value & 0.00 & & & 0.00 & & \\
\hline \multicolumn{7}{|l|}{ Test of over-identification } \\
\hline Chi-square & 0.18 & & & 0.29 & & \\
\hline$P$-value & 0.67 & & & 0.49 & & \\
\hline
\end{tabular}

Notes: $†$ Statistical significance at the $0.01(* * *), 0.05(* *)$ and $0.1\left(^{*}\right)$ level of probability.

coefficient of pest pressure (PRES) is positive, although it is not significant for the pesticide use function for export farmers. While the prevalence of pests might be expected to increase pesticide use, this suggests that exporters use pesticides as preventatives rather than in response to specific attacks. 
The parameter estimate for the level of training (TRAI) is negative and significant for the pesticide use function, pointing to a positive effect of agricultural training on reduction of pesticide use. As expected, the coefficient of distance to extension service (DIST), which is used as a proxy for access to information and advice, is positively and significantly associated with the expenditure on chemical pesticide, suggesting that farmers with more access to information and consultancy tend to reduce spending on pesticides. Household size (HHSI) in both functions is negatively correlated with pesticide use. This may suggest that the more members the household has the more labour is available for activities like weeding, which leads to reduction in herbicide usage. Age of the household head also seems to play a role in how much farmers spend on pesticides, i.e. younger vegetable farmers spend less than older farmers. The most interesting result is the coefficient that captures pesticide application (APPL). It was expected that the more a household head relied on hired casual labour to spray chemicals, the more pesticide would be used because of the shift of risk associated with pesticide spraying to another party. However, our results show a positive and significant correlation between the household head as primary applicator of pesticide and the spending on pesticides. Possibly, farmers who do the spraying themselves are able to use the money that would otherwise be spent on labour hire to buy more chemical pesticides.

\subsection{Stage 3: structural revenue model results}

The estimated revenue functions are aimed at investigating potential differences in the productivity of pesticides and total revenue among farmers producing for the domestic market vs. those producing for export market, and GlobalGAP adopters vs. non-adopters. The results for both samples are shown in Table 6. The models have a satisfactory explanatory power with adjusted $R$-square ranging from 0.3 to 0.4 , which is reasonable for a cross-sectional dataset. The $F$-statistic of the excluded instruments is greater than 10 for both second-stage models, thus passing the test for weak instruments. The two instruments work well according to the Hansen specification test of overidentifying restrictions.

The results of the revenue function estimated for all vegetable producers indicate that although there is a positive correlation between the decision to produce for export market (CRTY) and value of the crop yield, the coefficient is not significant. This result implies that export farmers and domestic farmers are indistinguishable in terms of revenue per acre earned during the long rainy season (Table 6). However, it would be expected that the revenue for export producers is higher if the dry season were to be included, for three basic reasons. First, the volume of sales for export producers is higher because of year-round production, unlike most domestic farms, which are seasonal. Second, the price of the export produce is relatively higher during the dry season because of high demand in most European countries, which could lead to higher returns. Third, exporter-oriented farmers have yearround access to markets, whereas domestic producers have a narrower marketing window.

The coefficient of GlobalGAP adoption (ADOP) is positive and significant in the revenue function estimated for export farmers, which indicates the positive impact 
of GlobalGAP adoption on total revenue per acre. Ceteris paribus, GlobalGAP adopters get $24 \%$ higher crop revenue than non-adopters. ${ }^{14}$

The results show that for both revenue functions, the expenditure on seed, pesticide and labour are the most important determinants of the final output obtained in vegetable fields. All these variables have the expected sign. Fertiliser is not significant in either sample. The coefficient of pesticide (PEST) shows that a $1 \%$ increase in pesticide expenditure in vegetable fields causes partial effectiveness of damage control input to increase by $0.002 \%$ for the first model and $0.003 \%$ for the second. As expected, product price (PRPR) has a positive impact on total revenue for both functions. The effects of seed (SEED) and labour (LABO) are positive and significant in both models. The expenditure on seed reflects both variety specifics such as the potential yield for a variety, and is a quality indicator, for instance in terms of germination rate. Theoretically, it could be expected that farm output would increase significantly with an increase in a farmer's management ability (measured in terms of the farmer's age). However, farmer's age (AGEH) is negatively associated with revenues here, albeit insignificantly for the exporters. Perhaps young farmers are more receptive to new varieties and management techniques and likely to face the risks associated with innovations that could lead to higher outputs. Two of the four district dummy coefficients (KIRINYAGA and MURANGA) have a negative sign, whereas the coefficient of one district (MAKUENI) has a positive sign. These indicate that farmers in the Meru district (reference district) have significantly more revenue from vegetable production compared with those in Kirinyaga and Muranga districts, but less compared with farmers in Makueni districts. Meru district is located at a higher altitude, which has favourable climatic condition for vegetable production. This results in high productivity, high quality and high prices for the produce. On the other hand, farmers in Makueni district have the advantage of using irrigation water. Farmers producing vegetables for the domestic market in Makueni district also have the advantage of delivering their produce to either Nairobi or Mombassa market, which could boost the price they receive, compared with farmers in other districts. ${ }^{15}$

Using the estimated coefficients presented in Table 6, the associated marginal value products (MVPs), and the actual and optimal amount of pesticides for GlobalGAP adopters, non-adopters and domestic farmers are computed and presented in Table 7. These computations are based on the assumption of all other inputs being

${ }^{14}$ Standard OLS estimation results of revenue function are presented in Appendix 1. The OLS estimates for participation in export market are larger and statistically more significant than the instrument variable estimates in the revenue function. Comparison with the OLS estimates shows that correction for unobservables is essential. The OLS estimates overestimate the revenue gain from participation in the export market because of the unobserved factors that matter for selection as export producers positively impact revenue from exporting. The IV and OLS estimates for adoption of GlobalGAP standards also show a difference both in terms of significance and magnitude. The OLS overestimate the income gain from adopting GlobalGAP standards.

${ }^{15}$ In an alternative model specification, which includes a set of dummies for types of vegetables produced instead of district dummies, we observed no significant change in the sign and level of significance of our interest variables although the significance level is changed by a small percentage for two variables (LABO and AGEH). The full results of this specification are available on request from the author. 
Table 6

Estimates of the revenue function

\begin{tabular}{|c|c|c|c|c|c|c|}
\hline \multirow[b]{3}{*}{ Variable } & \multicolumn{6}{|c|}{ Revenue function: ln-total revenue (KSh/acre) } \\
\hline & \multicolumn{3}{|c|}{$\begin{array}{c}\text { Domestic and export vegetable } \\
\text { producers }\end{array}$} & \multicolumn{3}{|c|}{$\begin{array}{c}\text { Export vegetable producers } \\
\text { only }\end{array}$} \\
\hline & $\begin{array}{l}\text { Estimated } \dagger \\
\text { coefficient }\end{array}$ & $\begin{array}{l}\text { Standard } \\
\text { error }\end{array}$ & $t$-value & $\begin{array}{l}\text { Estimated } \dagger \\
\text { coefficient }\end{array}$ & $\begin{array}{l}\text { Standard } \\
\text { error }\end{array}$ & $t$-value \\
\hline Constant & $8.19 * * *$ & 0.83 & 9.87 & $5.60 * * *$ & 1.05 & 5.32 \\
\hline CRTY estimated & 0.38 & 0.10 & 0.94 & & & \\
\hline ADOP estimated & & & & $0.27 * *$ & 0.12 & 2.30 \\
\hline SEED & $0.14 * * *$ & 0.04 & 3.54 & $0.22 * * *$ & 0.06 & 3.54 \\
\hline FERT & 0.03 & 0.04 & 0.88 & 0.07 & 0.07 & 1.02 \\
\hline LABO & $0.29 * * *$ & 0.06 & 4.50 & $0.37 * * *$ & 0.08 & 4.49 \\
\hline AGEH & $-0.38 * *$ & 0.16 & -2.35 & -0.28 & 0.20 & -1.40 \\
\hline CRNU & 0.09 & 0.12 & 0.77 & $0.23^{*}$ & 0.15 & 1.64 \\
\hline PRPR & $0.23 * * *$ & 0.07 & 2.89 & $0.20 * * *$ & 0.05 & 2.45 \\
\hline IRRI & 0.05 & 0.03 & 0.54 & 0.40 & 0.03 & 0.42 \\
\hline MARK & -0.14 & 0.10 & 1.32 & -0.13 & 0.08 & 1.45 \\
\hline FERL & 0.02 & 0.01 & 0.87 & 0.03 & 0.02 & 0.61 \\
\hline \multicolumn{7}{|l|}{ DISTRICTS } \\
\hline \multicolumn{7}{|l|}{ MERU (reference) } \\
\hline KIRINYAGA & $-0.53 * * *$ & 0.13 & -4.26 & $-0.50 * * *$ & 0.15 & -3.27 \\
\hline MURANGA & $-0.71 * * *$ & 0.18 & -3.89 & $-0.42^{*}$ & 0.25 & -1.70 \\
\hline NYERI & 0.09 & 0.14 & 0.66 & -0.01 & 0.17 & -0.04 \\
\hline MAKUENI & $0.48 * *$ & 0.22 & 2.17 & $0.65^{*}$ & 0.12 & 2.30 \\
\hline \multicolumn{7}{|l|}{ Damage control function } \\
\hline Constant $(\lambda)$ & $0.69 * * *$ & 0.26 & 2.66 & $0.68 *$ & 0.39 & 1.73 \\
\hline PEST estimated & $0.00 * * *$ & 0.00 & 3.29 & $0.00 * *$ & 0.00 & 2.46 \\
\hline Number of observations & 539 & & & 439 & & \\
\hline$R$-square & 0.37 & & & 0.34 & & \\
\hline Adjusted $R$-square & 0.35 & & & 0.31 & & \\
\hline \multicolumn{7}{|l|}{ Test of instruments } \\
\hline$F$-test (second stage) & 10.34 & & & 11.19 & & \\
\hline$P$-value & 0.00 & & & 0.00 & & \\
\hline \multicolumn{7}{|l|}{ Test of over-identification } \\
\hline Chi-square & 0.77 & & & 0.77 & & \\
\hline$P$-value & 0.38 & & & 0.38 & & \\
\hline
\end{tabular}

Notes: $†$ Statistical significance at the $0.01(* * *), 0.05(* *)$ and $0.1\left(^{*}\right)$ level of probability.

constant at the sample average values, while only varying the pesticide cost. For the logistic damage function specification, the derivation of the marginal value products of pesticide $\left(X_{p}\right)$ is obtained as follows:

$$
\frac{\partial Q}{\partial X_{p}}=\frac{Q}{1-\exp \left(\lambda-\alpha_{1} X_{p}\right)} * \alpha_{1} \exp \left(\mu-\alpha_{1} X_{p}\right) .
$$

The results demonstrate that the marginal value products per unit cost of pesticide are greater than unity for all cases, suggesting that all farmers (GlobalGAP 
Table 7

Estimated marginal value product of chemical pesticides (in KSh)

\begin{tabular}{|c|c|c|c|c|}
\hline \multirow[b]{2}{*}{ Variables } & \multicolumn{3}{|c|}{ Export market producers $(N=439)$} & \multirow{2}{*}{$\begin{array}{c}\text { Domestic } \\
\text { market } \\
\text { producers } \\
(N=100)\end{array}$} \\
\hline & $\begin{array}{l}\text { GlobalGAP } \\
\text { adopters }\end{array}$ & $\begin{array}{l}\text { Non- } \\
\text { adopters }\end{array}$ & Total & \\
\hline $\begin{array}{l}\text { Marginal value } \\
\text { products (KSh) }\end{array}$ & $5.61(2.43 * * *)$ & $1.64(1.96 *)$ & $5.84(2.64 * * *)$ & $21.04(3.77 * * *)$ \\
\hline $\begin{array}{l}\text { Actual pesticide } \\
\text { use (KSh/acre) }\end{array}$ & 1503 & 1860 & 1730 & 1093 \\
\hline $\begin{array}{l}\text { Optimal pesticide } \\
\text { use (KSh/acre) }\end{array}$ & 2135 & 2045 & 2595 & 2575 \\
\hline
\end{tabular}

Notes: Number in brackets shows a $t$-test compared to null hypothesis that MVP $=1$.

Statistical significance at the $0.01(* * *), 0.05(* *)$ and $0.1\left(^{*}\right)$ level of probability.

adopters, non-adopters and domestic vegetable producers) use pesticides below the financial optimum. Results of the $t$-tests compared with the null hypothesis that MVP $=1$ are all statistically significant below 10\% significance level (see Table 7). ${ }^{16}$ Domestic producers in particular are using pesticides at far below their optimal levels. For example, GlobalGAP adopters spend $630 \mathrm{KSh} /$ acre below the optimal level on pesticides; non-adopters use nearly $185 \mathrm{KSh} /$ acre less and domestic farmers spend almost $1,485 \mathrm{KSh}$ /acre less than optimal. Pesticide use below the financial optimum level has been reported for conventional cotton in West Africa (Ajayi, 2000) and Bacillus thuringiensis (BT) cotton in South Africa (Shankar and Thirtle, 2005). This underuse may have several causes, including financial constraints and the perceived risk of detectable pesticide residues leading to product rejection by exporters.

It is important to note however that the calculated optimal pesticide use levels do not take into account any environmental or health costs of pesticide use. If we assume a ratio of $1: 1$ for health costs alone (see Rola and Pingali, 1994), underuse of pesticide may no longer exist.

\section{Conclusions}

This study contributes to the growing literature on the implications of introducing food-safety standards in developing countries for farmers' production systems, using the case of Kenyan vegetable producers. Results show that farmers producing vegetables for the domestic market use significantly less pesticides than exporting farmers. Ceteris paribus, farmers producing for the export market spend $28 \%$ more on pesticides than farmers producing domestic crops. This study also showed that the

\footnotetext{
${ }^{16}$ MVP analysis might have shortcomings when applied to pesticide use in general because a marginal decision rule is predicated upon the assumption of a divisible input. Pesticide labels clearly state that they are to be treated like medicines and applied at standard rates for reasons of safety and efficacy. However, for most developing countries, this may not be the case because farmers' decision rule is determined by a number of constraints such as liquidity. Thus we believe that MVP analysis is informative on the decision of pesticide use.
} 
adoption of standards by the export farmers does not have any significant impact on the total expenditures on pesticides. In export vegetables, both adopters and non-adopters of standards still use pesticides at below the private economic optimum rate, though may be closer to optimal if the health and environmental side-effects of pesticide use are also considered. The adopter categories are distinguishable in terms of types of pesticide used, i.e. adopters use safer pesticides based on WHO classification, which support the hypothesis of standards contributing to modernisation of the export sector. The three-stage structural revenue model results demonstrate a positive and significant impact of standards adoption on revenue from vegetable production. The results also show that export and domestic farmers are indistinguishable in terms of total revenue earned per acre from producing vegetables, at least during the long rainy season.

While food safety and quality standards can be barriers preventing resource-poor smallholders from maintaining their position in the lucrative export markets (Asfaw et al., in press), they can also induce positive changes in the production systems of small-scale farmers who adopt it, as shown by the results presented. A shift to less hazardous pesticides as a result of GlobalGAP adoption can imply less pesticide intoxication by farmers and farm workers, less adverse impact on the environment and enhanced food safety.

Generally, the empirical results presented in this paper support the notion that the adoption of emerging food-safety standards can play a positive role by serving as a catalyst for transforming production systems towards safer and more sustainable operation. Hence, these standards can have health and environmental benefits aside from those that accrue for consumers in industrialised countries. Nevertheless, in order to extrapolate these results to the whole vegetable sector in Kenya, it is crucial to look closely at the scale of adoption of standards nationwide. According to data from FoodPlus secretariat, the legal body of GlobalGAP, and a separate survey by Mithöfer et al. (2008), the scale of adoption among export vegetable producers seems to be rather low (i.e. below $20 \%$ ) for achieving a direct significant impact within the smallholder vegetable export sector. Our data suggest that about 33\% of the sampled households adopted the standards during the survey season though this may not necessarily reflect the rate of adoption.

In previous farm-level analysis of determinants of GlobalGAP adoption in Kenya (Asfaw et al., in press), we identified lack of human capital (e.g. level of education of household members), physical capital (e.g. farm machinery) and social capital (e.g. group membership) as major determining factors that limit the adoption of standards by smallholders. The government and the private sector can help farmers to expand and upgrade their range of assets and practices to meet the new requirements of supermarkets and other coordinated supply chains. The options include public investment in increasing farmers' productivity and connectivity to markets, and promotion of collective action and the building of the technical capacity of farmers to meet the new standards.

\section{References}

Ajayi, O. O. C. Pesticide Use Practices, Productivity and Farmers' Health: The Case of Cotton-Rice Systems in Côte d'Ivoire, West Africa, Pesticide Policy Project No. 3 (Hannover: University of Hannover, 2000). 
Antle, J. M. and Capalbo, S. M. 'Pesticides, productivity and farmer health: Implications for regulatory policy and agricultural research', American Journal of Agricultural Economics, Vol. 76, (1994) pp. 598-602.

Antle, J. M. and Pingali, P. L. 'Pesticide, productivity and farmer health: A Philippine case study', American Journal of Agricultural Economics, Vol. 76, (1994) pp. 418-430.

Arendt, J. N. and Holm, A. Probit Models with Binary Endogenous Regressors, Discussion Paper No. 4 (Department of Business and Economics, University of Southern Denmark, 2006).

Asfaw, S., Mithöfer, D. and Waibel, H. 'What impact are EU supermarket standards having on developing countries export of high-value horticultural products? Evidence from Kenya', International Journal of Food and Agribusiness Marketing, in press.

Augier, P., Gasiorek, M. and Lai Tong, C. 'The impact of rules of origin on trade flows', Economic Policy, Vol. 20, (2004) pp. 567-623.

Dolan, C. 'The 'good wife': Struggles over resources in the Kenyan horticultural sector', Journal of Development Studies, Vol. 37, (2001) pp. 39-70.

GlobalGAP, GlobalGAP Protocol for Fresh Fruit and Vegetables (Cologne: GlobalGAP Secretariat, 2004; available at: http://www.globalgap.org; last accessed: April 2008).

Government of Kenya (GoK), Central Bureau of Statistics. 2006 Statistical Abstract (Nairobi: The Government Printer, 2006).

Greene, W. H. Econometric Analysis, 3rd edn (Upper Saddle River, NJ: Prentice-Hall, 1997).

Hausman, J. A. 'Specification tests in econometrics', Econometrica, Vol. 46, (1978) pp. 1251-1272.

Huang, J., Hu, R., Roelle, S., Qiao, F. and Pray, C. E. 'Transgenic variety and productivity of smallholder cotton farmers in China', Australian Journal of Agricultural and Resource Economics, Vol. 46, (2002) pp. 367-387.

Jaffee, S., van der Meer, K., Henson, S., de Haan, C., Sewadeh, M., Ignacio, L., Lamb, J. and Lisazo, M. B. Food-Safety and Agricultural Health Standards: Challenges and Opportunities for Developing Countries Export (Washington, DC: The World Bank, 2005).

Kennedy, P. E. 'Estimation with correctly interpreted dummy variables in semilogarithmic equations', American Economic Review, Vol. 71, (1981) pp. 801.

Lichtenberg, E. and Zilberman, D. 'The econometrics of damage control: Why specification matters', American Journal of Agricultural Economics, Vol. 68, (1986) pp. 261-273.

Maertens, M. and Swinnen, J. F. M. 'Standards as barriers and catalysts for trade and poverty reduction' (Paper presented at the 26th Conference of IAEA, Gold Coast, Australia, 12-18 August 2006).

Mausch, K., Mithöfer, D., Asfaw, S. and Waibel, H. 'Impact of EurepGAP standard in Kenya: Comparing smallholders to large-scale vegetable producers' (Paper presented at Tropentag, International agricultural research for development, Bonn, Germany 11-13 October 2006).

McCulloch, N. and Ota, D. M. Export Horticulture and Poverty in Kenya, Working Paper 174 (Brighton: Institute of Development Studies, 2002).

Mithöfer, D., Nang'ole, E. and Asfaw, S. 'Smallholder access to the export market: The case of vegetables in Kenya', Outlook on Agriculture, Vol. 37 (2008) pp. 203-211.

Pemsl, D. 'Economics of agricultural biotechnology in crop protection in developing countries: The case of Bt-cotton in Shandong province, China', Ph.D. Dissertation (Hannover: University of Hannover, 2006).

Pimentel, D. and Greiner, A. 'Environmental and socio-economic costs of pesticide use' in D. Pimentel (eds.), Techniques for Reducing Pesticide Use: Economic and Environmental Benefits (Chichester: John Wiley and Sons, 1997).

Pingali, P. L., Marquez, C. B. and Palis, F. G. 'Pesticide and Philippine rice farmer health: A medical and economic analysis', American Journal of Agricultural Economics, Vol. 76, (1994) pp. 587-592. 
Qaim, M. 'Bt cotton in India: Field trial results and economic projections', World Development, Vol. 31, (2003) pp. 2115-2127.

Qaim, M. and Zilbermann, D. 'Yield effects of genetically modified crops in developing countries', Science, Vol. 299, (2003) pp. 900-902.

Rivers, D. and Vuong, Q. H. 'Limited information estimators and exogeneity tests for simultaneous probit models', Journal of Econometrics, Vol. 39, (1988) pp. 347-366.

Rola, A. C. and Pingali, P. L. Pesticides, Rice Productivity and Farmers' Health - An Economic Assessment (Manila: IRRI, International Rice Research Institute, 1993).

Shankar, B. and Thirtle, C. 'Pesticide productivity and transgenic cotton technology: The South African smallholder case', Journal of Agricultural Economics, Vol. 56, (2005) pp. 97116.

Stock, J. and Staiger, D. "Instrumental variables regression with weak instruments", Econometrica, Vol. 65, (1997) pp. 557-586.

Thrupp, L. A., Bergeron, G. and Waters, W. F. Bittersweet Harvest for Global Supermarkets: Challenges in Latin America's Export Boom (Washington, DC: Natural Resources Institute, 1995).

Wilson, C. and Tisdell, C. 'Why farmers continue to use pesticides despite environmental, health and sustainability costs', Ecological Economics, Vol. 39, (2001) pp. 449-462.

Wooldridge, J. M. Econometric Analysis of Cross Section and Panel Data (Cambridge: The MIT Press, 2002).

\section{Appendix}

Table A1

Estimates of pesticide use and revenue function (OLS)

\begin{tabular}{|c|c|c|c|c|c|c|c|c|}
\hline \multirow[b]{3}{*}{ Variable } & \multicolumn{4}{|c|}{$\begin{array}{c}\text { Domestic and export vegetable } \\
\text { producers }\end{array}$} & \multicolumn{4}{|c|}{ Export vegetable producers only } \\
\hline & \multicolumn{2}{|c|}{ Pesticide use } & \multicolumn{2}{|c|}{ Revenue function } & \multicolumn{2}{|c|}{ Pesticide use } & \multicolumn{2}{|c|}{ Revenue function } \\
\hline & $\begin{array}{l}\text { Estimated } \dagger \\
\text { coefficient }\end{array}$ & $\begin{array}{l}\text { Stand. } \\
\text { error }\end{array}$ & $\begin{array}{l}\text { Estimated } \dagger \\
\text { coefficient }\end{array}$ & $\begin{array}{l}\text { Stand. } \\
\text { error }\end{array}$ & $\begin{array}{l}\text { Estimated } \dagger \\
\text { coefficient }\end{array}$ & $\begin{array}{l}\text { Stand. } \\
\text { Error }\end{array}$ & $\begin{array}{l}\text { Estimated } \dagger \\
\text { coefficient }\end{array}$ & $\begin{array}{l}\text { Stand. } \\
\text { error }\end{array}$ \\
\hline ADOP & & & & & $-0.11 *$ & 0.92 & $0.31 * * *$ & 0.09 \\
\hline CRTY & 0.17 & 0.09 & $0.49 * *$ & 0.08 & & & & \\
\hline PEPR & $0.70 * * *$ & 0.02 & & & $0.14 * * *$ & 0.03 & & \\
\hline FEPR & $-0.07 * * *$ & 0.00 & & & $-0.03 * * *$ & 0.001 & & \\
\hline AGEH & -0.01 & 0.00 & $-0.30 * *$ & 0.15 & $-0.01 * *$ & 0.00 & $-0.22 *$ & 0.17 \\
\hline HHSI & $-0.05^{*}$ & 0.03 & & & $-0.05^{*}$ & 0.02 & & \\
\hline PRES & $0.07 * *$ & 0.03 & & & 0.04 & 0.03 & & \\
\hline CONT & 0.04 & 0.03 & & & 0.05 & 0.02 & & \\
\hline GROU & $0.20 *$ & 0.02 & & & 0.04 & 0.02 & & \\
\hline SYPT & $0.04 *$ & 0.04 & & & $0.05^{*}$ & 0.03 & & \\
\hline FACI & -0.14 & 0.09 & & & $-0.27 * * *$ & 0.10 & & \\
\hline TRAI & $-0.06^{*}$ & 0.01 & & & -0.02 & 0.02 & & \\
\hline DIST & $0.10 * * *$ & 0.02 & & & $0.05^{* *}$ & 0.02 & & \\
\hline CRED & $0.00^{*}$ & 0.00 & & & 0.00 & 0.00 & & \\
\hline APPL & $0.42 * * *$ & 0.15 & & & $0.39 * * *$ & 0.16 & & \\
\hline FERL & -0.01 & 0.02 & & & 0.03 & 0.02 & & \\
\hline SEED & & & $0.11^{* *}$ & 0.02 & & & $0.23 * * *$ & 0.06 \\
\hline FERT & & & 0.03 & 0.04 & & & 0.07 & 0.07 \\
\hline LABO & & & $0.31 * * *$ & 0.06 & & & $0.37 * * *$ & 0.08 \\
\hline
\end{tabular}


Table A1

(Continued)

\begin{tabular}{|c|c|c|c|c|c|c|c|c|}
\hline \multirow[b]{3}{*}{ Variable } & \multicolumn{4}{|c|}{$\begin{array}{c}\text { Domestic and export vegetable } \\
\text { producers }\end{array}$} & \multicolumn{4}{|c|}{ Export vegetable producers only } \\
\hline & \multicolumn{2}{|c|}{ Pesticide use } & \multicolumn{2}{|c|}{ Revenue function } & \multicolumn{2}{|c|}{ Pesticide use } & \multicolumn{2}{|c|}{ Revenue function } \\
\hline & $\begin{array}{l}\text { Estimated } \dagger \\
\text { coefficient }\end{array}$ & $\begin{array}{l}\text { Stand. } \\
\text { error }\end{array}$ & $\begin{array}{l}\text { Estimated } \dagger \\
\text { coefficient }\end{array}$ & $\begin{array}{l}\text { Stand. } \\
\text { error }\end{array}$ & $\begin{array}{l}\text { Estimated } \dagger \\
\text { coefficient }\end{array}$ & $\begin{array}{l}\text { Stand. } \\
\text { Error }\end{array}$ & $\begin{array}{l}\text { Estimated } \dagger \\
\text { coefficient }\end{array}$ & $\begin{array}{l}\text { Stand. } \\
\text { error }\end{array}$ \\
\hline CRNU & & & 0.09 & 0.10 & & & $0.26^{* *}$ & 0.13 \\
\hline PRPR & & & $0.24 * * *$ & 0.06 & & & $0.20 * * *$ & 0.04 \\
\hline IRRI & & & 0.07 & 0.03 & & & 0.03 & 0.03 \\
\hline MARK & & & $-0.15^{*}$ & 0.08 & & & $-0.12^{*}$ & 0.06 \\
\hline FERL & & & 0.03 & 0.01 & & & 0.04 & 0.02 \\
\hline \multicolumn{9}{|l|}{ DISTRICTS } \\
\hline \multicolumn{9}{|l|}{$\begin{array}{l}\text { MERU } \\
\text { (reference) }\end{array}$} \\
\hline KIRINYAGA & $-0.19^{*}$ & 0.19 & -0.16 & 0.14 & $-0.19 *$ & 0.22 & $-0.45^{* *}$ & 0.14 \\
\hline MURANGA & 0.10 & 0.30 & $-0.62 * *$ & 0.17 & $0.68 * *$ & 0.38 & -0.40 & 0.22 \\
\hline NYERI & -0.02 & 0.18 & 0.10 & 0.14 & 0.12 & 0.21 & -0.10 & 0.22 \\
\hline MAKUENI & $-0.67 * *$ & 0.28 & $0.32 *$ & 0.21 & $-0.97 * * *$ & 0.40 & $0.44^{*}$ & 0.09 \\
\hline \multicolumn{9}{|c|}{ Damage function } \\
\hline Constant $(\lambda)$ & & & $0.42 * *$ & 0.24 & & & $0.45^{* *}$ & \\
\hline PEST & & & $0.01 * *$ & 0.00 & & & $0.10^{*}$ & \\
\hline $\begin{array}{l}\text { Number of } \\
\text { observations }\end{array}$ & 539 & & 539 & & 439 & & 439 & \\
\hline $\begin{array}{l}R \text {-square/ } \\
\text { Adj. } R \text {-square }\end{array}$ & $0.32 / 0.27$ & & $0.39 / 0.36$ & & $0.39 / 0.33$ & & $0.35 / 0.31$ & \\
\hline
\end{tabular}

Note: $†$ Statistical significance at the $0.01(* * *), 0.05(* *)$ and $0.1(*)$ level of probability. 